\title{
Induction and isolation of tumor antigen-specific CD4+ T lymphocytes using sorting signal directed MHC class-II expression
}

\author{
Christian Ellinger ${ }^{*}$, Carina Wehner, Susanne Wilde, Dolores J Schendel, Slavoljub Milosevic \\ From Society for Immunotherapy of Cancer 28th Annual Meeting \\ National Harbor, MD, USA. 8-10 November 2013
}

The adoptive transfer of tumor-antigen specific CD8+ T lymphocytes has shown highly promising but somewhat limited benefit in tumor immunotherapy. The poor objective clinical efficacy observed in early studies has been overcome partly by integration of patient preconditioning and improved technologies for $\mathrm{T}$ cell receptor gene therapy. Nevertheless, in accordance with results from peptide vaccine studies, we hypothesize that further improvement in therapeutic efficacy can be achieved through addition of tumor-antigen specific CD4+ T lymphocytes. CD4+ T cells provide pivotal help for activated cytotoxic $\mathrm{T}$ cells, especially by reducing exhaustion upon chronic antigen stimulation, and by supporting tumor infiltration capacity. In addition, CD4+ T lymphocytes are critical for the initiation of long lasting CD8+ T cell memory and can also exert direct antitumor effector functions, even in the absence of MHC class II expression. To support a systematic evaluation of potentially beneficial effects of CD4+ T cells in the adoptive $\mathrm{T}$ cell transfer setting, we developed an efficient method for the activation and isolation of tumor-antigen specific CD4+ T lymphocytes. Using selected tumor/testis antigens fused to cell internal sorting signals, we were able to utililze dendritic cells transfected with in vitro transcribed RNA for the efficient induction of tumor-antigen specific CD4+ T cells. Via antibody-mediated staining of CD40ligand (CD40L) on the surface of specifically reactivated peripheral blood lymphocytes (PBL), we successfully isolated multiple tumor-antigen specific $\mathrm{CD} 4+\mathrm{T}$ cell clones with diverse $\mathrm{MHC}$ class II allotype restrictions. Moreover, a method for the direct identification of $\mathrm{CD} 4+\mathrm{T}$ cell epitops (DEPI) enabled us to define novel MHC-II restricted

Institute of Molecular Immunology, Helmholtz Zentrum Muenchen, German Research Center for Environmental Health, Munich, Germany epitopes within the targeted tumor/testis antigens. Currently, isolated tumor-antigen specific CD4+ T cell clones are assessed for direct and indirect effector mechanisms to determine the possible contributions of $\mathrm{CD} 4+\mathrm{T}$ lymphocytes in the immunotherapy of cancer.

Published: 7 November 2013

doi:10.1186/2051-1426-1-S1-P6

Cite this article as: Ellinger et al:: Induction and isolation of tumor antigen-specific CD4+ T lymphocytes using sorting signal directed MHC class-II expression. Journal for ImmunoTherapy of Cancer 2013 1(Suppl 1): P6.
Submit your next manuscript to BioMed Central and take full advantage of:

- Convenient online submission

- Thorough peer review

- No space constraints or color figure charges

- Immediate publication on acceptance

- Inclusion in PubMed, CAS, Scopus and Google Scholar

- Research which is freely available for redistribution
C Biomed Central
C Biomed Central

(0) 2013 Ellinger et al; licensee BioMed Central Ltd. This is an Open Access article distributed under the terms of the Creative Commons Attribution License (http://creativecommons.org/licenses/by/2.0), which permits unrestricted use, distribution, and reproduction in any medium, provided the original work is properly cited. 